\title{
Politics, An Illusion We Have Forgotten Is Such
}

\author{
Bradley Kaye
}

\section{(Dis)Ability and Capitalist Production}

Emerging work on disability is only beginning to examine the relation between the mode of production and the oppressed disabled body. For instance, the work of Marta Russell and Ravi Malhotra[1] has brilliantly articulated disability as being external or marginal in relation to capitalism's mode of production. In my opinion, we can include mad subjects in this analysis who are placed similarly in oppression as a disposable population outside of production. Russell and Malhotra claim the social model of disability necessitates a rethinking of prevalent definitions. Leaving aside biological or physical-anthropological definitions of disability which make it appear that impaired persons are 'naturally' and therefore justifiably, excluded from the 'labour force', even mainstream definitions have serious shortcomings. Reconceptualizing disability as an outcome of the political economy, however, also requires acknowledging the limitations of the 'minority' model of disability, which views it as the product of a disabling social and architectural environment.

In this view the fundamental source of the problems encountered by disabled persons is prejudicial or discriminatory attitudes, implying that by erasing mistaken attitudes society will accept 'difference' and equality will flourish. This approach diverts attention from the mode of production and the concrete social relations that produce the disabling barriers, exclusion and inequalities facing disabled persons. In contrast, Russell and Malhotra take the view that disability is a socially-created category derived from labour relations, a product of the exploitative economic structure of capitalist society: one which creates (and then oppresses) the so-called 'disabled' body as one of the conditions that allow the capitalist class to accumulate wealth. Seen in this light, disability is an aspect of the central contradiction of capitalism, and disability politics that do not accept this are, at best, fundamentally flawed strategies of reform or, worse, forms of bourgeois ideology that prevent this oppression from being seen.

First, let me examine an ableist existential philosopher - Martin Heidegger. His work on Dasein (his term for subjectivity) may illuminate the distinction between ableism and the work of Jean Baudrillard, who can be evoked to illuminate a position of liberation for the mad. Martin Heidegger is famous for claiming that Dasein is facticity. This means that it has consciousness of itself as destined to become-X. Dasein always has space presented as already discovered though not thematically. For Heidegger, Being-in-the-world is the goal of Dasein, to feel one with nature and the world. Time is always a correlate to being and one cannot be in the world without also being within time.

However, as Baudrillard points out time and time again in his oeuvre, the world is extremely dysfunctional. Time is out of joint. To take this point even further, it is not so problematic that the world is merely dysfunctional because dysfunction can be solved pragmatically. Rather, the problem that gnaws at the marrow of Jean Baudrillard's writings must be the purely nihilistic question: what if the world does not exist at all? If we take Baudrillard seriously, and I certainly do, then we can begin to see the world through the eyes of a madman. In doing this, we also grant madness subjectivity, something that Martin Heidegger neglected to do.

The question becomes complex: how do we construct a viable political ontology outside of there being a posited objective reality? This is one possible question to ask Heidegger over coffee in heaven. What if there is no world out there with which Dasein strives to be unified? In reading Baudrillard one must admit that perhaps Heidegger 
was completely off base. Moreover, no such thing as 'side-by-sideness' of an entity called Dasein with another entity called 'world' exists. In fact, if we can refer to something called world and entity, these concepts are always already alien to the self. Singularity, and not ego, is mutually co-imbricating us together at all times. It is our separateness that is the illusion borne out of an objective notion of reality. Dreaming of a unity to come beyond alienation is to give madness a telos. For conservatives on the right, selfhood is the basis of politics because sovereignty enables the preservation of rights - one of which is liberty and the power to make free choices. For Baudrillard, politics does not always serve the interests of the fully flourishing self (see anything that Baudrillard wrote). In fact, these allegedly innate liberties, stifled by social institutions such as the State, are nothing more than decadent illusions masking a more nefarious set of forces lurking behind the scenes. If Baudrillard must have a label it is beyond Marxism into the realm of Anarchy; which is described by Saul Newman as being merely the philosophy of power and its unmasking (Newman 2007). In Baudrillardean terms anarchism amounts to demystifying the illusion that passes as actually existing homogenous reality as all there is, and ever could be. By extension, anarchism is politically positing beliefs that this one-reality can be constructed otherwise. Closer to the point would be to construe reality as not being a unity at all, but rather a loose conglomeration of antagonisms, differences and political striations to be pushed to the extreme through breaking prohibitions and taboos enclosing our imaginative possibilities.

\section{| Imaginative Possibility of C-M-C}

One such imaginative possibility is the movement beyond M-C-M[2] productive-circulation to C-M-C, or even potlatch and gift exchange. This is why Georges Bataille was such an influence on Baudrillard and many of his contemporaries. In this work, I will later explore the overlapping discourses of potlatch as being a possible panacea to productive exclusions.

In the analysis offered by Karl Marx, M stands for Money and C stands for commodities. According to Marx, this represents the true ground for communist revolution. The total transformation of the modes of production will not be complete without the radical alteration of circulation. In capitalism one must have capital $(M)$ to put into the creation of commodities in order to get an increased return on the capital investment, which is called profits. Capital (M) must be procured either through inheritance, or banks, in order to produce a commodity, which will be sold at a higher price than the raw materials and the labor necessary to produce the commodity $(\mathrm{C})$ and profits are accumulated by the class that has access to the capital (the bourgeoisie), which are then reinvested through speculation on other capitalist projects. Capitalism is always an economy based on class conflict because the capitalists have access to investment and because the ideological superstructure (courts, the state, protectors of the ideology of private property) enforces the contracts that bind labor to capital in an exploitative way, as well as provide the economic base out of which capital can derive its labor supply, the process of circulation is unabated by meager reforms. The only way to fully transform this M-C-M to C-M-C (where the working class produces its own commodities, which it then sells for money, and exchanges with other workers for other commodities, a system without profit - communism) is through revolution that smashes the state and collectivizes the modes of production[3].

Anarchist-Socialists also posit this as being a necessary step to bring about radical change. This revolution may not only benefit disabled people, but anyone who has the fruit of their labor expropriated at the benefit of capital. Left unabated, this circulation process continues until there are no resources left and the raw materials run out, which creates the fall in the rate of profit, and a crisis emerges. Or rather, when labor keeps cutting into the profits of capital by demanding higher wages, capital must see a dip in profits to stave off total revolution, but this economy is fragile and precarious, boom and bust cycles of crisis, with a steady dose of ideology constantly keep the proletariat in line. Libidinal investments do the job as well, but also the precarious position of bodies excluded from production place them in a position of propertylessness (object free workers)[4]. This means the disabled literally have no property to sell, not even like their exploited counterparts the able-bodied workers.

According to Marx, this was the first characteristic of the revolutionary subject. Being able-bodies is not necessarily the best situation either. Dictated by social conditions workers are compelled to sell the whole of their active life, and their very capacity for labor, in return for the price of his customary means of subsistence. Marx explains the dire situation of even workers expropriating their labor: "to sell his birthright for a mess of pottage" (Marx 1977; pg. 382).

Clearly, the exploitation described by Marx in the three volumes of Capital constitutes a palpable feeling of 
disgust in most readers. The descriptions of brutal working conditions, child labor and wages bordering on slavery should be enough to evoke a widespread revolt against capitalism, and Marx hoped that it would. However, the one thing Marx could not predict in the 19th century was the way in which bourgeois illusions would seep into the proletariat deluding us/them into believing that revolution was hopeless. Louis Althusser's analysis of the ideological superstructures provides cogent analysis of how capitalism keeps everyone in their place. Mainly, two theses emerge from Althusser: Ideology represents the imaginary relationship of individuals to their real conditions of existence; and ideology has a material existence. Once capital gets hold of the subjugated subject from within then it can beckon, or call the subject through interpellation as an individual.[5]

Being disabled puts you even beneath the position of the worker totally dependent upon state assistance merely to survive and more often than not unable to find adequate wages to maintain life beyond mere subsistence. Money taken out of circulation is wealth and this can only be accumulated by capital because labor must always remain within circulation as a result of their wages only being paid out in miniscule increments barely enough to stay alive. Workers rarely have savings because wages are only enough to reproduce themselves materially. Disabled bodies do not even have the potential to do even this basic reproduction, and according to Marta Russell and Ravi Mahlotra, this places the disabled in a position to accept even more extreme forms of exploitation out of sheer desperation to survive.

One of many really smart things Jean Baudrillard said went like this: the demystification of value will show reality, and by extension politics, for the illusions that they always already are. Baudrillard explains: 'the human species comes to consciousness through the imaginary, and always already enmeshed in illusions. Production, labor, value, everything objective is imaginary.' It is not illusion that conceals reality, but reality that conceals there is none. In my opinion, this constitutes a statement in favor of the politics of pathos. It constitutes an illusion manifesting a cogent critique of the end of history from within. To think that capitalism is the only way humans can exist and that no other social order will ever emerge is to live in the matrix. To think that there can only be production and nothing otherwise to make the same mistake Marx made in mirroring production. In other words, the conditions of capitalism exist unchanged precisely by remaining tied to the vestiges of production, and not turning to other social organizations such as gift-exchange, potlatch or something else.

\section{Bataille, Baudrillard, Eco-Illusions}

By turning to Baudrillard there can be political possibilities that do not mirror production and do not reproduce a capitalist metaphysics of value. Certain excluded populations, such as the mad, the disabled and the lumpenproletariat already exist outside production. Stepping outside of the metaphysics of value involves evoking particular tactics such as the refusal of work, which other theorists such as Giorgio Agamben, Antonio Negri, and Slavoj Zizek all discuss in various places, along with Julian Pefanis' Heterology and the Postmodern: Bataille, Baudrillard, and Lyotard, and his The Mirror of Production.

Baudrillard is an end of history critic whose work can be understood in the contemporary world conjuncture as an agent of pathos within the austere institutional dimensions of real subsumption. By turning to Baudrillard we can draw a salient critique of these homogenizing tendencies (which appear as reality, but are quite illusory). We need to imagine other possible worlds that do not hinge on oppression, violence and the decadent materialist syllogisms of 'productive-consumption'. Like a map that covers the entire globe, the hyperreal brings humans to consciousness in the imaginary but forces us to believe in something called reality 'out there', stable for anyone to know objectively. My reading of Baudrillard concludes that various political a-priori transcendental truths are a trick of the bourgeoisie (the one truly a-historical class).

The social importance of this work is to hopefully give a voice to a population that has historically been silenced, precisely because they/we have been codified as pathological: the mad (with all of our heterogeneous modes of expression as beings-in-the-world). If pathos has been historically situated as a silence, then we must begin to grapple with the very real possibility that psychology will never be able to accommodate within its space that which constitutes the absence of the signatory, to say nothing of the absence of a referent.

This writing may become a historical outlier, externality or clothing with which to construct a new methodological dressage towards the silence that has been construed as 'pathos/madness.' Baudrillard speaks on behalf of the disenfranchised, the mad and the pathological justifiably alienated from an otherwise dysfunctional capitalist regime 
of exploitation, greed, and nihilistic pleasure seeking. Baudrillard is the penultimate theorist who thinks through a politics of pathos in an empowering way, as an always already unthinkable silence that is all around at all times.

For Baudrillard, I would argue, freedom as it is paradigmatically misunderstood in Neo-Liberalism, constitutes a state of ignorance regarding the market forces. These forces are at play homogenizing collective behaviors through various machinations of production. True freedom constitutes a break with production. It is precisely the determination of force, or rather the determining factors of forceful coercion elided by our notions of freedom, choice and privacy. One of the most provocative treatments of this problem has to be Jean Baudrillard's oft-neglected tract, The Mirror of Production. In this text, Baudrillard infuses a bleak set of principles into his work on political economy, and indeed coupling this with his work during the 1980's, notably Simulacra and Simulation, what we are left with is a new critical theory speaking precisely to this being-as-situation.

It blends elements of Marxism, Deconstruction, Nihilism, Carnivalesque Spectacle, as well as Science Fiction, and this fusion in my opinion is best described as Critical Madness Theory. It may allow for new discursive approaches to madness. The overarching theme Baudrillard deals with throughout his entire life, was to discredit any notion of a stable reality - in fact, the mask deluding us into believing there are no illusions, is the premise of objective reality. The illusion has become real, and to borrow from Nietzsche, "Truth is an illusion we have forgotten is such" (Nietzsche 1977). Yet, what would happen if we could remember that all is an illusion? Well, it would be madness.

However, that is precisely when political liberation would be likely to occur and the creativity of aesthesis could flourish. If all is an illusion, then all is politics. According to Baudrillard's good friend Michel Foucault, politics is war by other means, not the other way around. The entire terrain of the hyperreal, the map that covers the illusion and appears as if it were real, is in fact, the place of guerilla warfare. Even the ignorant who feign bliss are in the trenches jockeying for position vicariously through ballot boxes and often literally through material conditions. As Louis Althusser claimed, ideology is not revealed in what a person says, but in how a person acts. Politics always amounts to examining the preferred methods of reproduction.

At its very core, the heart of the battle over ascension to political hegemony must be a battle over modes of production. Not merely material production, but also ontological and metaphysical production, that means the productions of self and the productions of what passes for reality. A mode is like a Spinozian mode - what exists now is merely one mode out of the infinity of possible expressions that can possibly be produced. Each mode exists on a continuum connected through various loci, or centers, that push out, extending through other territories, like power flowing upon an electrical grid, through networks, relays, passages and currents. Pointedly, currency is the biggest mode of power as expressed in capitalism, but currency is always a hyperreal illusion (perhaps even delusion) the hegemonic class, grasping the levers of the state apparatuses pull over on its citizens. Because the value imposed upon money is social, and never intrinsic, just like power exerted by the state itself. Once the social construction of value, or what may be best called 'the-money-delusion', becomes accepted as if it were real then the sheep stay in line. As Baudrillard rightly tells us, there is no such thing as an intrinsic metaphysics of value. Liberation involves picking away at the delusion that value is intrinsic, when in fact it is a socio-political contingency. If value is a contingency, then it can change, if it can change, then all bets are off, because what is liberated is aesthesis and human creativity.

Political truth is the biggest illusion because it does not exist, yet many people act under the pretense that it does. As Baudrillard said:

I am a nihilist. I observe, I accept, I assume the immense process of the destruction of appearances (and of the seduction of appearances) in the service of meaning (representation, history, criticism, etc.)

Continuing he says:

I observe, I accept, I assume, I analyze the second revolution that of the twentieth century, that of postmodernity, which is the immense process of the destruction of meaning, equal to the earlier destruction of appearances. He who strikes with meaning is killed by meaning. (Baudrillard 1981; pg. 160-61)

Postmodernity - (is that even a philosophy?) - is reaching a point of saturation in a most disturbing state of inertia. The flow of postmodernity, or as I see it, the decadent cocoon of spectacle that makes us all egotistical Cartesians (in the sense that the only thing we can prove beyond a reasonable doubt actually exists is ourselves - literally solipsistic delusions of total isolation - the matrix indeed!). That this bourgeois dream-wish of perfect isolation in privacy, to ward off the barbarians yapping at the gates in perfect isolation behind our walls, to be completely detached from the Other, is to be in the postmodern end of history. However dialectical life may be, in 
the sense that nobody can exist like this forever, the simulacrum created by bourgeois ideology can only last until the money runs out. It is to feign to have what one doesn't have.

Nobody really knows how the end of the world will happen. It may happen by the hands of righteous politicians, or it may happen because this God we failed to kill has had enough of our bullshit. It is time to realize, the clock is ticking and the biggest illusion is the saturation of all aspects of life with pointless spectacles and meager relationships with associates we barely know. This is the hyperreal that passes itself off as reality itself, and it has lead to the total destruction of the environment, the breakdown of any semblance of meaningful community and the rise of reactionary forces that attempt to counteract these decadent forces with spiritual weapons. If Baudrillard was correct then he knew his Nietzsche well: Decadence always begins with the willing of nothingness. Any civilization in a state of decline would rather actively will nothingness, than to will nothing at all. Productivity abounds, even in during the twilight of the idols, but it cannot stop the final cresting in which the dominant paradigms and cultural meanings that glued its people together, no longer make sense. The falcon cannot hear the falconer; mere anarchy is loosed upon the world (W.B. Yeats; The Second Coming 1956).

\section{The Politics of Pathos}

This is the madness that Baudrillard discusses, and it can liberate Mad-beings from the sarcophagus of objective reality. It illuminates the uncertainty that abounds in postmodernism, while also escaping from the ennui of working in an office-coffin or a textual dreamlike trance. Politics is all textual, inter-textual relational play, and by extension does not exist objectively. There are no truths out there in the world to be known with absolute certainty, and yet faith gets us nowhere closer to the real either. Madness is the only standby to trust in a pinch, it keeps us longing for more and more bizarre methods of procuring and producing pleasure, to ward off the doldrums of another nihilistic endurance test in our factory lives. Even our death is not our own. It is prepackaged with religious overtones; judgments and sacrifice. It is the mad call of pathos.

In contemporary society, perhaps a different kind of enlightenment is happening without recourse to reason. From Plato's allegory of the cave, and the mysteries of representation that the slaves must liberate themselves from to be free, history may be linked necessarily to madness, characterized by Michel Foucault as the "absence of work"[6] (because work is the condition of citizenry). At the heart of culture is a "we" formed on a split between those in possession of reason and those without it. Jean Baudrillard often shows that the great split between reason and unreason is an illusion, because more often than not, what passes for reason is the immanence of unreason.

What Baudrillard does that is provocative, is his usage of the pathological as legitimating political subjectivity. It is the mode of production that marginalizes the pathological as if they/we are not fully functional human beings. So, by extension, madness is a disability constructed within the framework of productivity of capitalism. In fact, Baudrillard is not necessarily saying exactly the same thing as Marta Russell and Ravi Malhotra, but their work on disability bears an affinity with the way Baudrillard at times depicts madness.

By turning to Baudrillard, the politics of madness, described as liberating the disabled (or perhaps to be politically correct, differently abled) mind can only be liberated by shattering the mirror of production. Georges Bataille's Accursed Share volume one is an integral text for Baudrillard scholarship. He claims, "The world of the subject is the night: that changeable, infinitely suspect night which, in the sleep of reason, produces monsters."[7] Positing madness itself gives a rarified idea of the free "subject," unsubordinated to the "real" order and occupied merely with the present and forgetful of the future. As Georges Bataille explains in a general economy consumption and madness go hand in hand:

\footnotetext{
The subject leaves its own domain and subordinates itself to the objects of the real order as soon as it becomes concerned for the future. For the subject is consumption insofar as it is not tied down to work. If I am no longer concerned about "what will be" but about "what is," what reason do I have to keep anything in reserve? I can at once, in disorder, make an instantaneous consumption of all that I possess.[8]
}

Being outside of the production-work nexus is the depiction Bataille, and by extension his influence stretches also to Baudrillard, Lyotard, Foucault, Deleuze and others. What is at stake is the jouissance, the pleasure drawn from actively pursuing an inevitable demise. To take pleasure in being at work next to a machine decades at a time only to wind up deaf, because after all it is always either suffer in exploitation or die, the illusory choice of Neo- 
Liberalism - the only delusion to be disavowed is the rather incredible situation we are in whereby the vast majority of proletarians actually accept rather than resist this sadistic lot in life. To walk softly into the jaws of hell and not take the easy way out - death, is the unspeakable horror that shows the immense power of ideology - the famous line by Karl Marx "they do not know it, yet they are doing it" is precisely the point. Not merely do they not know it, but may indeed find sexual gratification from the debasement of exploitation. To learn to submit the bulk of one's day to labor, rather than live in idleness is the greatest trick the bourgeoisie play on the working classes and it constitutes a widely accepted political illusion that a situation where workers have nothing to sell but their bodies is somehow the best situation for the majority. Ideology is symptomatic of the social milieu within which it is constructed. To address the ideological symptoms is to ignore the base, or root of the problem, which is the exploitation released by the mode of production.

\section{| Symptoms and Ideology}

A symptomatic ideological simulation knows no bounds. For instance, take the attempts to integrate a deterritorialized subject back into a general economy rampant with transgressions. It often results in lines of flight, a symptom of recidivist schizophrenic anti-production. Remember what Marx and Engels famously said about capitalist morality: "All that is solid melts into air" amidst the constant pseudo-revolutionizing of production where changes appear to be occurring all the time even though the bourgeoisie maintain hegemony over the ownership of production. To be truly schizophrenic, if we take Deleuze and Guattari seriously, is to posit a viable resistance to the ideology of production. It may be a simulated illness with real symptoms, much like capitalist ideological symptoms wherein the illusion has posited as 'real' in the sense that it clothes itself in the garb of the 'natural'. Ideological symptoms in capitalism pass-as-if it were human nature (whatever that is), because of the Neo-Liberal notion that we are all free to construct our lives however we choose, the illusion is that we choose to be exactly how we are in capitalism. The end of history rears its ugly head yet again.

Whoever fakes an illness can sit in bed and make everyone believe he is ill, but to simulate an illness involves showing symptoms. Literally producing the illness in the subject through sheer will constitutes the basis of antiproduction and self-negation. Pretending still leaves the principle of reality in tact, it simply masks reality, whereas simulation blinds us to the distinction between real and unreal, truth and illusion, real and imaginary. Is a simulator sick or not considering that he produces allegedly real symptoms?

Baudrillard has the following statements regarding the phenomenon of psychosomatic illnesses:

Objectively one cannot treat him as being either ill or not ill. Psychology and medicine stop at this point, forestalled by the illness's henceforth undiscoverable truth. For if any symptom can be "produced," and can no longer be taken as a fact of nature, then every illness can be considered as simulatable and simulated, and medicine loses its meaning since it only knows how to treat "real" illnesses according to their objective causes. (Baudrillard 1981; pg. 3).

Liberalism needs utopia. Utopia is the logic of any meta-narrative that attempts to give history a productive telos. However, this production will expand until it reaches its material limit. Liberalism cannot exceed the limit of its resources, and the hyperreal will last only as long as the money flows. The new capital is human capital, the exploitation of bodies, the usage of the entrepreneurial self, or what Michel Foucault called, "Homo Economicus", a relatively new social phenomenon. What passes as responsible political economy, is actually a chaotic orgy. Jean Baudrillard's politics is reminiscent of Georges Bataille's famous essay, "The Sorcerer's Apprentice", which is a line drawn from Capital, but shows a line of demarcation where postmodernism resists all Modernisms (ala dialectics). As Bataille nihilistically claims: "Contemporary men can master only a heap that represents the debris of existence." (Bataille 1985; pg. 233). Perhaps it is possible that the totality of our existence is nothing more than a simple dream a hyperreal delusion of which we are doomed to never wake up, perhaps until a revolutionary subject emerges from the rubble. As all great anarchist-socialists would agree, the greatest harm that strikes modern man is perhaps the reduction of their existence to the state of a servile organ. Serving multiple masters is impossible. One cannot pray to the god of money and the god in heaven, but strip away all that was once holy, rob us of the fetters of deism and all that we are left with is the cold-calculus of pure profit-seeking. In this breakdown of the sacred, if God is indeed dead, then we are all little more than whores. To put it another way, God is dead and we are his gravediggers, capital will create the conditions of its own gravediggers in radicalizing the proletarian subjects through exploitation, and 
if God is dead, then what will replace it as the Transcendental Signifier? The holy trinity of Greed: Capital, Money, and Commodity Fetishism.

Yet, without a moral base to cling to in the hope of positing an ethical utopia, we are teetering on horizon lines of flight becoming an immanent component of production. Not to fetishize production or factories, but I am posing a rupture to the base that breaks through with new anti-productive agents. The mad, the disabled, the deviants, the marginal among others hold a place where revolutionary subjectivity could emerge out of this omni-crisis at any time. It is the biggest trick of all that this delusional game continues on and actually works to maintain some semblance of hegemonic order where the subjects remain predominantly in place. Mythos of greed is all it takes to devalue our existence to the point of mere subjection. Georges Bataille clearly influenced Baudrillard on this point quite eloquently: "Myth is perhaps fable, but this fable is placed in opposition to fiction if one looks at the people who dance it, who act it, for whom it is living truth" (Bataille 1985; pg. 232).

It is the myth that holds the community together in solidarity with total existence, of which it is a tangible expression. To have a community, to feel togetherness, one must also identify those who are outside of the group. Any national identity, any community, must have a constitutive outside; an enemy-Other. More over, politics in its most barbaric form has been the playing out of the crudest manifestation of this baseline ideology "Us" versus "Them". Transcendence of this horrific distinction is more or less impossible, probably because it is instinctually borne out of the lower regions of our territorial reptilian brain, a stratified vestige of the Paleolithic Era. Capital does little to assuage this lower functioning violence of our primal drives. The illusion is that the violence is merely hidden in privacy, and out on the margins away from the hegemonic upper classes. In fact, establishing moral high ground on prohibitions and taboos merely makes the thrill of transgression much more intense.

This is why Bataille and Baudrillard often claimed they were searching for the terror of evil. Evil is love. More often than not, this is true, but not in the sense of a naturalism. Yet, if ideology is used as the rationality of capitalism then this quote represents a pseudo-anti-naturalism, rather than naturalization. Denaturalizing nature, a preeminent trait of resistance moving towards libidinal escalation, rupture, and transgression. Moreover, Transgression cannot be a commodity, it is irreducible to fetishism primarily because commodities are forms, and transgressions are the antithesis of all form. Transgression is the rupture of form. Transgression is the purity of formlessness. Transgression is reminiscent of the lumpenproletariat propertylessness of a body external to production. If this analysis of transgression and form makes sense, then Antonio Negri was alluding to a Bataillean-Baudrillardean point in Marx Beyond Marx: "Proletarian violence is symptomatic of communism." (Negri 1979; pg.174). To suppress violence created out of class composition is to deliver the proletariat tied hand and foot over to capital.

The holy trinity I spoke of earlier: Capital, Money, Commodity are emptied forms, but not yet constitutive of political formlessness. These movements constitute the epitome of sacred decadence. Form without content. What a nihilist would do is breakdown all the dimensions of form. This involves stepping beyond the claim issued by Walter Benjamin at the end of his Art in the Age of Mechanical Reproduction that history has reaches the apogee of alienation where humans can experience their own destruction as an aesthetic pleasure of the highest form. "This situation of politics which Fascism is rendering aesthetic. Communism responds by politicizing art." (Benjamin; 2007; pg. 241). It is not necessarily in line with what Friedrich Nietzsche called the plight of those within the confines of slave-morality who are doomed to merely, 'stylize their freedoms' (Nietzsche 1977). There is hope, but the hope will not take the form of peaceful protest, but rather violent resistance breaking down prohibitions. Replacing this "No" of prohibitive asceticism with the "Yes" of hedonistic transgression. Politics, in this sense, is an illusion we have forgotten is such.

\section{Endnotes}

1. Russell, Marta, and Malhotra, Ravi. "Capitalism and Disability”. Socialist Register, volume 38.

2. Marx, Karl. Grundrisse. Penguin Classic Edition 1973. Pg. 201-203
3. See also - Lyotard, Jean-Francois. Libidinal Economy, pg.95-155 \& 201-243. Lyotard's analysis of the pre-depression era of speculative capital in America during the 1920's is eerily reminiscent of the lead up to the Global Financial Crisis in 2008. Politics 
gives us the illusion of change, when the real factors that lead to change are the relations of capital, money, and circulation. Sovereignty is nothing more than the meek inheritors of market forces often beyond the control of a lone head of state.

4. Marx, Karl. Grundrisse. Penguin Classic Edition 1973. Pg. $507 \& 513$

5. Althusser, Louis. Ideology and Ideological State Apparatuses.
6. Foucault, Michel. "Folie et deraison: histoire de la folie a l'age classique". "absence of work" is the translation of "une absence d'oeuvre", pg. 15.

7. Bataille, Georges. The Accursed Share volume one. Zone Books. New York, 1991. Pg. 58.

8. Ibid.

\section{References}

Bataille, Georges. 1985. Visions of Excess. "The Sorcerer's Apprentice.” Minnesota Press. Minneapolis.

Baudrillard, Jean. 1972. The Mirror of Production. Telos Press. New York.

Benjamin, Walter. 2007. Illuminations. Harcourt Press. New York.

Deleuze, Gilles and Felix Guattari. 1984. Anti-Oedipus: Capitalism and Schizophrenia.

Marx, Karl. 1977. Capital volume one. Vintage Press. New York.
Newman, Saul. 2007. From Bakunin to Lacan. Lexington Books. Lexington, Kentucky.

Nietzsche, Friedrich. The Portable Nietzsche. "On Truth and Lying in an Extra Moral Sense.” ed. Walter Kaufmann.

Yeats, W.B. 1955. Collected Poems. The Second Coming. Oxford. London. 